\title{
Urinary excretion of purine derivatives and tissue xanthine oxidase (EC 1.2.3.2) activity in buffaloes (Bubalis bubalis) with special reference to differences between buffaloes and Bos taurus cattle
}

\author{
BY X. B. CHEN, L. SAMARAWEERA, D. J. KYLE AND E. R. ØRSKOV \\ Rowett Research Institute, Bucksburn, Aberdeen AB2 $9 S B$ \\ AND H. ABEYGUNAWARDENE \\ Faculty of Veterinary Medicine, Peradeniya University, Peradeniya, Sri Lanka
}

(Received 24 August 1994 - Revised 13 April 1995 - Accepted 9 June 1995)

\begin{abstract}
The urinary excretion of purine derivatives (PD) was measured in six buffaloes (Bubalis bubalis) during fasting and in fourteen buffaloes given four restricted levels of roughage $(2.5-4.8 \mathrm{~kg} \mathrm{DM} / \mathrm{d})$. Only allantoin and uric acid, not xanthine and hypoxanthine, were present in the urine, the pattern of excretion being similar to that in cattle. The fasting PD excretion amounted to 0.20 (SD 0.06) $\mathrm{mmol} / \mathrm{kg}$ metabolic weight $\left(W^{0 \cdot 75}\right)$ per $d$, and the rate of $P D$ excretion as a linear function of feed intake was $5.2 \mathrm{mmol} / \mathrm{kg}$ digestible organic matter intake. Both values were considerably lower than the values for cattle reported in the literature. Creatinine excretion values were 0.33 (SD 0.06) and 0.44 (SD 0.09) $\mathrm{mmol} / \mathrm{kg} \mathrm{W}^{0.75}$ per d determined in fasting and feeding periods respectively. Fasting $N$ excretion was 257 (SD 49) $\mathrm{mg} \mathrm{N} / \mathrm{kg} \mathrm{W}^{075}$ per d. Both creatinine and fasting $\mathrm{N}$ excretions were also lower than in cattle. The activities of xanthine oxidase $(E C$ 1.2.3.2) in plasma, liver and intestinal mucosa were determined in buffaloes, cattle and sheep. Xanthine oxidase activities in buffaloes were 24.5 (SD 2.7) unit/l plasma and 0.44 (SD 0.02) and 0.31 (SD 0.10) unit/g fresh tissue in liver and intestinal mucosa respectively. These activities were higher than those in cattle and sheep. Xanthine oxidase was practically absent from plasma and intestine of sheep. It is suggested that the differences in PD excretion between buffaloes and cattle were probably due to the smaller proportion of plasma PD that was disposed of in the urine of buffaloes.
\end{abstract}

Buffalo: Purine derivatives: Xanthine oxidase

The urinary excretion of purine derivatives (PD; i.e. allantoin, uric acid, hypoxanthine and xanthine) by ruminants can be used to estimate the intestinal flow of microbial protein once the endogenous excretion of PD and the quantitative relationship between PD excretion and purine absorption have been determined. This technique has so far been used in sheep, cattle and goats to estimate the flow of purines into the intestine, from which microbial protein flow can be inferred (Lindberg, 1989; Verbic et al. 1990; Balcells et al. 1991; Chen et al. 1991; Dewhurst \& Webster, 1992). It is desirable for the technique to be extended to buffaloes (Bubalis bubalis), a species which is of considerable economic importance in many tropical countries. However, there has been limited information reported in the literature about the purine metabolism and PD excretion in this species.

Published studies have shown that there are species differences in purine metabolism. Sheep and Bos taurus cattle, for example, are known to differ both in their level of endogenous purine excretion and in their ability to utilize exogenous purines (Chen et al. 1992). Similarly, differences have been found between other species such as camels 
(Camelus dromedarius), Zebu (Bos indicus) cattle (Mura et al. 1986) and red deer (Cervus elaphus; Maloiy et al. 1970). The results of studies by Vercoe (1976) and Liang et al. (1993) indicated that the excretion of allantoin (the main component of PD) per unit of digestible DM intake was lower in buffaloes than in cattle. Whether this was due to a lower endogenous excretion, or a change in composition of PD was, however, not clear. In the present paper we report some preliminary observations on the excretion of $\mathrm{PD}$ in urine during fasting and at different levels of feed intake, which could provide indications of the magnitude of the endogenous PD excretion and of the response of PD excretion to feed intake. Our interest was to see whether these PD excretion measurements in buffaloes were comparable with those for cattle reported in the literature. We also report measurements in buffaloes, cattle and sheep of the tissue activities of xanthine oxidase (XO;EC 1.2.3.2), a key enzyme for purine degradation.

\section{EXPERIMENTAL}

The animal experimental work was carried out at the Buffalo Research Station, Narangalla, Sri Lanka.

\section{Expt 1. Urinary excretion of purine derivatives during fasting}

Animals and feeding. Five female buffaloes (Murrah $\times$ Local, live weight $222-262 \mathrm{~kg}$, approximately 2.5 years old) were used. The animals were individually penned with restricted movement and fed with $2.5 \mathrm{~kg}$ rice straw $/ \mathrm{d}$ supplemented with urea $(10 \mathrm{~g} / \mathrm{kg}$ straw on fresh weight basis), for 2 weeks and then fasted for $6 \mathrm{~d}$. The rice straw contained $924 \mathrm{~g} \mathrm{DM} / \mathrm{kg}$ fresh weight, $823 \mathrm{~g}$ organic matter (OM) $/ \mathrm{kg} \mathrm{DM}$ and $7 \cdot 1 \mathrm{~g} \mathrm{~N} / \mathrm{kg} \mathrm{DM}$.

Excreta collection. Daily urine was collected from the animals during the last $4 \mathrm{~d}$ of the feeding period and throughout the fasting period. During the collection period, technicians were assigned to collect the urine manually from the animals at time of urination $24 \mathrm{~h}$ daily. Urine was collected into buckets containing $500 \mathrm{ml} 1 \mathrm{M}-\mathrm{H}_{2} \mathrm{SO}_{4}$ for each day to ensure a final $\mathrm{pH}$ of urine between 2 and 3. The daily urine was then diluted up to four times with water and subsamples were taken and stored at $-20^{\circ}$ for analysis of $P D$, creatinine and $N$.

\section{Expt 2. Urinary excretion of purine derivatives at different levels of feed intake} Animals and feeding. Fourteen female Murrah $\times$ Local buffaloes with body weights of $188-256 \mathrm{~kg}$ were used. All animals were approximately 2.5 years old. They were allocated to four groups which were given one of the four levels of restricted intake $(2 \cdot 0,2 \cdot 5,3 \cdot 5$ and $4.5 \mathrm{~kg}$ fresh weight $/ \mathrm{d})$ of rice straw but supplemented with the same amount $(0.75 \mathrm{~kg} / \mathrm{d})$ of coconut poonac (a concentrate feed made after extraction of oil from coconut). The DM contents were 924 and $872 \mathrm{~g} \mathrm{DM} / \mathrm{kg}$ fresh weight, OM contents 823 and $804 \mathrm{~g} / \mathrm{kg} \mathrm{DM}$ and $\mathrm{N}$ contents $7 \cdot 1$ and $40 \cdot 1 \mathrm{~g} / \mathrm{kg} \mathrm{DM}$ for rice straw and coconut poonac respectively. Total DM intakes at the four levels were $2 \cdot 50,2 \cdot 96,3 \cdot 89$ and $4 \cdot 81 \mathrm{~kg} / \mathrm{d}$. The animals were housed in pens and were kept on the feeding regimen for a 3-week period. During the last $5 \mathrm{~d}$, collections of urine and faeces were made.

Excreta collection. The procedure for urine collection was as in Expt 1. Faeces were collected daily and sub-samples were taken and bulked for each animal at the end of each period for DM and ash determination.

\section{Expt 3. Xanthine oxidase activity in plasma, liver and intestine}

Measurements of XO in samples of buffalo plasma, liver and intestine were made at the Veterinary Research Institute, Peradeniya, Sri Lanka, while XO in sheep and cattle samples was measured at the Rowett Research Institute, Aberdeen. Samples of plasma, liver and intestine were taken either at the local slaughter houses (liver, intestine and plasma, taken 
from the same animals and the plasma taken before slaughter) or at the research institutes (plasma). All samples were taken randomly with respect to age, breed, sex or previous nutritional status.

Sampling and preparation of tissue extracts. Jugular blood samples from six buffaloes, four cattle and four sheep were collected into heparinized tubes. They were centrifuged at $2500 \mathrm{~g}$ for $10 \mathrm{~min}$ at $4^{\circ}$ and plasma was used for the assay within $2 \mathrm{~h}$.

Liver samples were taken from four buffaloes, three cattle and five sheep. They were washed in cold $0 \cdot 15 \mathrm{M}-\mathrm{KCl}$, blotted dry and frozen immediately. A $1 \mathrm{~g}$ sample of liver was homogenized in $9 \mathrm{ml} 0.5 \mathrm{~mm}-\mathrm{EDTA}$ in $0.05 \mathrm{M}-\mathrm{KH}_{2} \mathrm{PO}_{4}(\mathrm{pH} 7.5)$ in a glass homogenizing tube with a Teflon pestle. The extract was centrifuged at $40000 \mathrm{~g}$ for $30 \mathrm{~min}$ at $4^{\circ}$. The supernatant fraction was dialysed against the same EDTA-K $\mathrm{H}_{2} \mathrm{PO}_{4}$ buffer at $4^{\circ}$ for $24 \mathrm{~h}$, and centrifuged at $40000 \mathrm{~g}$ for $30 \mathrm{~min}$ at $4^{\circ}$. The supernatant fraction was used for the assay.

Intestinal samples were taken from four buffaloes, three cattle and six sheep. The first $300 \mathrm{~mm}$ segment of the small intestine was taken and the lumen washed with cold $0 \cdot 15 \mathrm{M}$ $\mathrm{KCl}$ and then with $0.05 \mathrm{M}-\mathrm{N}$-2-hydroxyethylpiperazine- $\mathrm{N}^{\prime}$-2-ethanesulphonic acid (HEPES) buffer (pH 7.5) containing 0.25 mM-EDTA and 0.25 M-phenylmethylsulphonyl fluoride (PMSF). The segment of intestine was cut lengthwise, opened flat and the mucosal surface carefully scraped with a spatula in order to isolate the mucosal cells. A $1 \mathrm{~g}$ sample of mucosal cells was then homogenized in $9 \mathrm{ml}$ HEPES-EDTA-PMSF buffer and centrifuged. The supernatant fraction was dialysed at $4^{\circ}$ for $24 \mathrm{~h}$ against the same buffer, and the dialysate centrifuged as for the liver samples.

The above procedure for preparation of liver and intestinal samples was adapted from Furth-Walker \& Amy (1987).

Xanthine oxidase activity. Activity of $\mathrm{XO}$ was measured as the rate of uric acid production when xanthine was incubated with the plasma or tissue extracts. The incubation mixture contained: $0.5 \mathrm{ml}$ sample (plasma, liver or mucosa extract), $3 \mathrm{ml} 0.05 \mathrm{M}-\mathrm{KH}_{2} \mathrm{PO}_{4}$ (pH 7.5) buffer and $0.5 \mathrm{ml}$ substrate solution. The substrate solution contained $1.5 \mathrm{~mm}$ xanthine, $4.3 \mathrm{~mm}$-L-histidine and 1.0 mm-potassium oxonate. L-Histidine was added to remove the possible inhibition of XO by excess xanthine (Muraoka, 1963) while potassium oxonate was added to inhibit uricase (EC 1.7.3.3; Hashimoto, 1974). The reaction mixture was incubated at $37^{\circ}$ for up to $60 \mathrm{~min}$. At intervals of $10 \mathrm{~min}$ incubation was terminated and the reaction stopped by addition of $0.5 \mathrm{ml} 1000 \mathrm{~g} / 1$ TCA to the reaction mixture. The mixture was then centrifuged at $40000 \mathrm{~g}$ for $30 \mathrm{~min}$ at $4^{\circ}$, and the absorbance of the supernatant fraction read at $292 \mathrm{~nm}$. The amount of uric acid produced was calculated based on a standard curve established using uric acid, and described as a monoexponential function of incubation time $(t, \min ): Y=a+b\left(1-\mathrm{e}^{-k t}\right)$, where $Y$ is the cumulative production of uric acid $(\mu \mathrm{mol}), a$ is the initial amount $(\mu \mathrm{mol})$ of uric acid present in the reaction system, $b$ the potential production of uric acid $(\mu \mathrm{mol})$, and $k$ the fractional rate of uric acid production. The curve fitting was aided by the Maximum Likelihood Program (MLP) of Ross (1987). The rate of uric acid production was calculated as $b \times k(\mu \mathrm{mol} / \mathrm{min})$. One unit of $\mathrm{XO}$ activity was defined as $1 \mu \mathrm{mol}$ uric acid produced per min at $37^{\circ}$ with excess substrate.

\section{Chemical analysis}

Allantoin was measured using HPLC (Chen et al. 1993). Uric acid, xanthine and hypoxanthine were measured on an autoanalyser (Chen et al. 1990 b). In the latter method the sum of xanthine and hypoxanthine was measured as uric acid after treatment of the sample with XO. Creatinine in urine was determined using the method of Larsen (1972). All daily urine samples were analysed individually. DM and ash contents of feed and faeces were determined by the method of the Association of Official Analytical Chemists (1965). 


\section{Statistical analysis}

The relationship between PD excretion and feed intake was examined by linear regression analysis. Single-factor ANOVA was performed to compare the differences between PD excretion measurements between the feeding and fasting periods in Expt 1, and between the four levels of feed intake (Expt 2). The XO activities for each tissue between species were also compared by ANOVA. The statistical analysis was aided by Genstat 4 (Lawes Agricultural Trust, 1983).

\section{RESULTS}

Expt 1. Urinary excretion of purine derivatives, creatinine and nitrogen during fasting Xanthine and hypoxanthine were not detectable in buffalo urine and thus total PD included only allantoin and uric acid. The allantoin: uric acid molar ratio was $0 \cdot 90: 0 \cdot 10$. There was no clear trend of changes in PD excretion during fasting. Average daily PD excretion was almost the same $(P>0.05)$ during the periods of feeding and fasting $(0 \cdot 19$ (SD 0.03) $\mathrm{mmol} / \mathrm{kg}$ metabolic weight $\left(\mathrm{W}^{0.75}\right)$ v. 0.20 (SD 0.06) $\mathrm{mmol} / \mathrm{kg} \mathrm{W}^{0.75}$ ). The CV for PD excretion averaged $31 \%$ between days for each animal and $13 \%$ between animals. Daily creatinine excretion averaged 0.28 (SD 0.08) and $0.33(\mathrm{SD} 0.06) \mathrm{mmol} / \mathrm{kg} \mathrm{W}^{0.75}$, and daily $\mathrm{N}$ excretion 222 (SD 46) and 257 (SD 49) $\mathrm{mg} / \mathrm{kg} \mathrm{W}^{0.75}$ for the feeding and fasting periods respectively. There were no significant differences $(P>0.05)$ between the two periods in these measurements. The $\mathrm{CV}$ of daily measurements within each individual animal ranged from 25 to $40 \%$ for PD, creatinine and $\mathrm{N}$ measurements. However, when $\mathrm{PD}$ and $\mathrm{N}$ were expressed as a ratio to creatinine, the $\mathrm{CV}$ was smaller (about $9 \%$ ).

The volume of urine excreted increased as a result of fasting and with the duration of fasting. The last day's urine outputs were 5.0, 2.7, 1.5, 1.9, 4.4 and 4.5 times the average daily urine output of the feeding period $(3.9,6 \cdot 7,7 \cdot 1,2 \cdot 7,2 \cdot 3,3 \cdot 7$ litres/d) in the six buffaloes respectively. The rapidity of the response varied between animals: the response occurred on the first day of fasting in three animals and fifth or sixth day of fasting in the other three animals.

\section{Expt 2. Urinary excretion of purine derivatives at different levels of feed intake}

As in Expt 1, no xanthine or hypoxanthine was detected in the urine. The results for daily excretion of PD are presented in Table 1. The differences in the daily PD excretion between the four treatments did not reach statistical significance $(P>0.05)$ due to the small differences in the digestible organic matter intake (DOMI). However, there were significant correlations between PD excretion $(\mathrm{mmol} / \mathrm{d})$ and digestible DM intake (DDMI, $\mathrm{kg} / \mathrm{d}$ ) and $\operatorname{DOMI}(\mathrm{kg} / \mathrm{d})$ :

$$
\begin{array}{ll}
\mathrm{PD}=10 \cdot 8(\mathrm{SE} 2 \cdot 9)+4 \cdot 51(\mathrm{SE} 1 \cdot 4) \mathrm{DDMI} & (r 0.63, n 14, P<0.01) \\
\mathrm{PD}=10 \cdot 3(\mathrm{SE} 2 \cdot 7)+5.23(\mathrm{SE} 1 \cdot 6) \text { DOMI } & (r 0.64, n 14, P<0.01)
\end{array}
$$

The mean value for the intercepts of equations 1 and 2 indicated an excretion of $10.5 \mathrm{mmol} \mathrm{PD} / \mathrm{d}$ at zero feed intake, which was equivalent to $0 \cdot 18 \mathrm{mmol} / \mathrm{kg} \mathrm{W}^{0.75}$ per d. Addition of the quadratic term of feed intake $\left(\mathrm{DDMI}^{2}\right.$ or $\left.\mathrm{DOMI}^{2}\right)$ to equations 1 and 2 respectively however did not improve the correlation coefficient, indicating that there was no quadratic effect of feed intake on the PD excretion. Moreover, when body weight (BW) was included in the regression analysis, i.e. replacing DDMI with the DDMI: BW ratio, there was no improvement in the correlation coefficient. Creatinine excretion averaged $0 \cdot 44$ (SD 0.09) $\mathrm{mmol} / \mathrm{kg} \mathrm{W}^{0.75}$ per d, higher than the measurement obtained in Expt 1.

\section{Expt 3. Xanthine oxidase activity in plasma and tissues}

Fig. 1 shows the production of uric acid when xanthine was incubated with plasma or tissue extracts from buffaloes, cattle and sheep, as an indication of XO activities. The calculated 
PURINE EXCRETION IN BUFFALOES

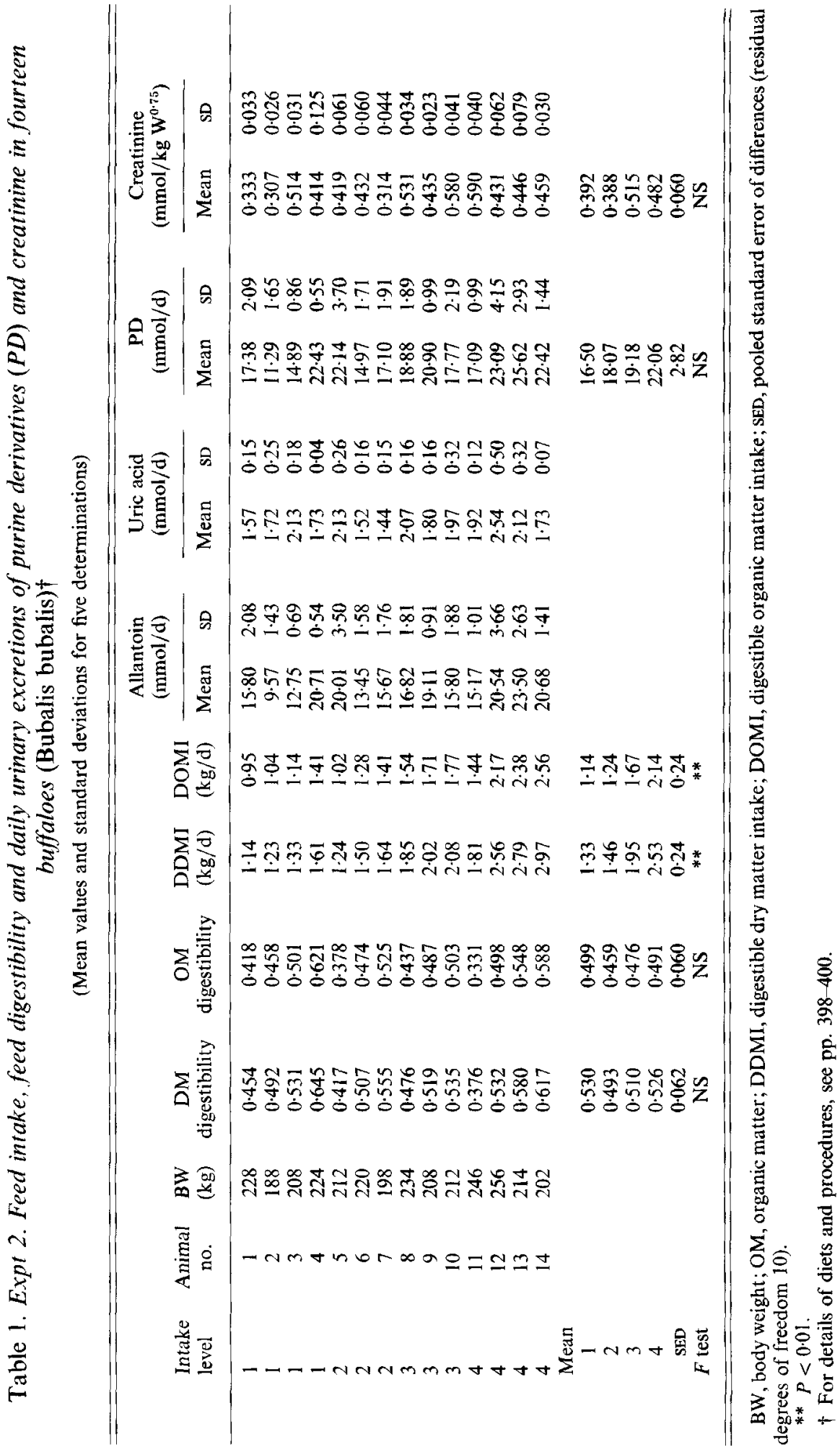



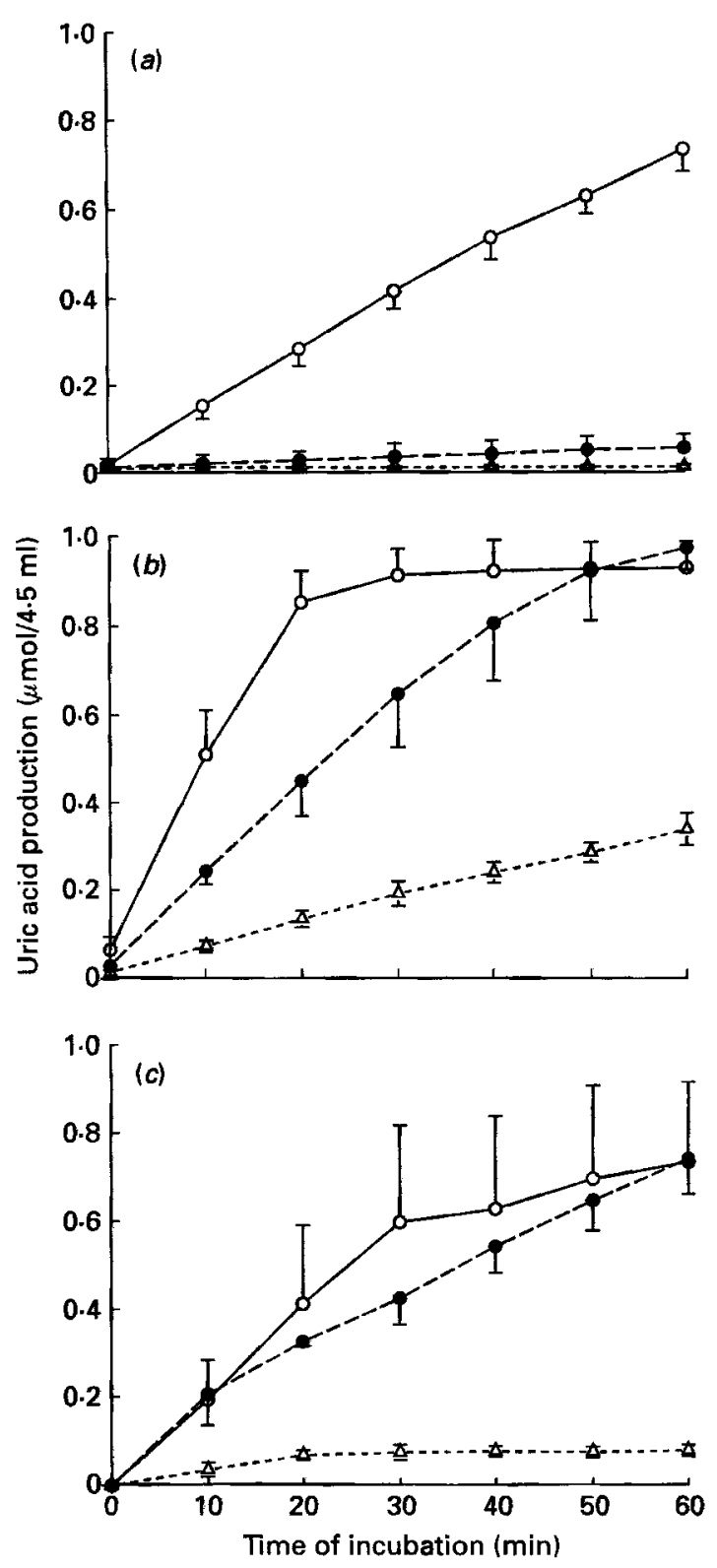

Fig. 1. Expt 3. Production of uric acid when xanthine was incubated with (a) plasma, (b) liver extract or (c) intestinal mucosa extract from buffaloes $(O)$, cattle $(\bullet)$ and sheep $(\triangle)$. Values are means with standard deviations indicated by vertical bars; the numbers of animals included are given in Table 2 . For details of procedures, see pp. 398-399. 
Table 2. Expt 3. Activities of xanthine oxidase (EC 1.2.3.2) in plasma, liver and intestine of buffaloes (Bubalis bubalis), cattle and sheep ${ }^{\dagger}$

\begin{tabular}{|c|c|c|c|c|c|c|c|c|}
\hline & \multicolumn{2}{|c|}{ Buffaloes } & \multicolumn{2}{|c|}{ Cattle } & \multicolumn{2}{|c|}{ Sheep } & \multirow[b]{2}{*}{ SED } & \multirow[b]{2}{*}{$F$ test } \\
\hline & Mean & SD & Mean & SD & Mean & SD & & \\
\hline Plasma (unit/l) $\ddagger$ & \multicolumn{2}{|c|}{$\begin{array}{c}\left.24.5{ }_{(n}\right)^{2 \cdot 70} \\
\end{array}$} & \multicolumn{2}{|c|}{${ }_{(n 4)}^{1.4} 0$} & \multicolumn{2}{|c|}{$\begin{array}{ll}0 & \\
& (n 4)\end{array}$} & $1 \cdot 52$ & $* *$ \\
\hline Liver (unit/g wet tissue) $\ddagger$ & \multicolumn{2}{|c|}{$\begin{array}{l}0.444_{(n)}^{0.02} \\
(n)\end{array}$} & $\begin{array}{r}0.30 \\
\quad(n\end{array}$ & $0 \cdot 10$ & \multicolumn{2}{|c|}{$\begin{array}{c}0.08 \\
(n 5)\end{array}$} & 0.03 & $* *$ \\
\hline Intestine (unit/g wet mucosa cell) $\ddagger$ & $\begin{array}{r}0.31 \\
(n\end{array}$ & $0 \cdot 10$ & $0 \cdot 18$ & 0.02 & 0.04 & 0.01 & 0.06 & $* *$ \\
\hline
\end{tabular}

\footnotetext{
** $P<0.01$ (residual degrees of freedom 29).

$\dagger$ For details of procedures, see pp. 398-399.

$\ddagger$ One unit is defined as $1 \mu \mathrm{mol}$ uric acid produced per min at $37^{\circ}$.
}

$\mathrm{XO}$ activities are presented in Table 2. The XO activities were consistently higher in buffaloes than in cattle and sheep in all tissues. Scarcely any was found in the plasma and in the intestinal mucosa of the sheep.

\section{DISCUSSION \\ Pattern of purine derivatives in urine}

The pattern of PD excreted in the urine of buffaloes resembled that in cattle in the following ways: (1) xanthine and hypoxanthine were absent ; (2) the proportion of allantoin: total PD $(0.89$, SD 0.026$)$ was within the range previously observed in cattle $(0.86-0.91$; Verbic et al. 1990; Chen et al. 1992). Such a profile of urinary PD for buffaloes was expected in the light of the high XO activities in plasma and the tissues studied.

\section{Excretion of purine derivatives during fasting and in response to feed intake}

In Expt 1, daily PD excretion during the feeding period was not significantly different from that during the fasting period, probably because there was little input of exogenous purines from the rumen microbial biomass at a low level of straw intake and thus the daily excretion was close to the endogenous excretion. Moreover, the onset of fasting did not seem to have caused abrupt change in PD excretion in this study, again due to the relatively small alteration in nutrient input. If the value for the fasting period $\left(0.20 \mathrm{mmol} / \mathrm{kg} \mathrm{W}^{0.75}\right.$ per d) is taken as an estimate of the endogenous PD excretion, it would indicate that the endogenous excretion in buffaloes could be about 0.4 of that previously noted in cattle $\left(0.530 \mathrm{mmol} / \mathrm{kg} \mathrm{W}^{0.75}\right.$, Chen et al. $1990 c$; and $0.485 \mathrm{mmol} / \mathrm{kg} \mathrm{W}^{0.75}$, Verbic et al. 1990).

It was to our surprise that the increase in PD excretion with the increasing level of straw intake was small so that the differences did not reach statistical significance. This was the result of the small range of straw intakes imposed and of the poor quality of rice straw (OM digestibility averaged 0.48 ). However, there was a positive response of PD excretion to the feed intake. The regression approach was used to examine the effect of feed intake on PD excretion. Equations 1 and 2 describe the response of PD excretion to level of digestible feed intake. The response appears linear since the fitted intercept (or the estimated endogenous contribution) of $0.18 \mathrm{mmol} / \mathrm{kg} \mathrm{W}^{0.75}$ per $\mathrm{d}$ was close to the measured fasting PD excretion $\left(0.20 \mathrm{mmol} / \mathrm{kg} \mathrm{W}^{0.75}\right.$ per $\left.\mathrm{d}\right)$. Despite the variation between animals and thus the error attached to the fitted parameters of regression, the slopes of the regression lines (4.50 mmol PD $/ \mathrm{kg}$ DDMI or $5.23 \mathrm{mmol} \mathrm{PD} / \mathrm{kg}$ DOMI), which indicate the rate of PD excretion per $\mathrm{kg}$ digestible $\mathrm{OM}$ or DM intake, were lower than expected based on the 
Table 3. Summary of results reported in the literature on excretion of allantoin in response to digestible dry matter intake (DDMI) in cattle and buffaloes

( $\mathrm{A}$ and $\mathrm{B}$ are the fitted intercept and slope of the linear regression line)

\begin{tabular}{|c|c|c|c|c|c|}
\hline Reference & Animal & $\underset{(\mathrm{mmol} / \mathrm{d})}{\mathrm{A}}$ & $\begin{array}{c}\text { B } \\
(\mathrm{mmol} / \mathrm{kg} \\
\text { DDMI })\end{array}$ & $\begin{array}{c}\mathrm{W} \\
(\mathrm{kg})\end{array}$ & $\begin{array}{c}\mathrm{A} \text { as } \\
\mathrm{mmol} / \mathrm{kg} \\
\mathrm{W}^{0 \cdot 75}\end{array}$ \\
\hline Daniels (1993) & $\begin{array}{l}\text { Cattle } \\
\text { (Bos taurus })\end{array}$ & $31 \cdot 0$ & $14 \cdot 7$ & 508 & 0.29 \\
\hline Vercoe (1976) & $\begin{array}{l}\text { Cattle } \\
\text { (Bos taurus) }\end{array}$ & $23 \cdot 5$ & $15 \cdot 4$ & $500^{*}$ & $0 \cdot 22$ \\
\hline Liang et al. (1993) & $\begin{array}{l}\text { Cattle } \\
\text { (Bos indicus) }\end{array}$ & 3.9 & $14 \cdot 9$ & $500^{*}$ & 0.04 \\
\hline Giesecke et al. (1993) & $\begin{array}{l}\text { Cattle } \\
\text { (Bos taurus) }\end{array}$ & - & $14 \cdot 2 \dagger$ & - & - \\
\hline Chen et al. (1992) & $\begin{array}{l}\text { Cattle } \\
\text { (Bos taurus) }\end{array}$ & - & $14 \cdot 5 \ddagger$ & $\ldots \ldots . .$. & \\
\hline Lindberg \& Murphy (1991) & $\begin{array}{l}\text { Cattle } \\
\text { (Bos taurus) }\end{array}$ & - & $24 \ddagger$ & 485 & \\
\hline Vercoe (1976) & Buffalo & $18 \cdot 1$ & 6.6 & $500^{*}$ & $0 \cdot 17$ \\
\hline Liang et al. (1993) & Buffalo & $3 \cdot 2$ & $8 \cdot 3$ & $500^{*}$ & 0.03 \\
\hline Present work & Buffalo & $9 \cdot 2$ & $4 \cdot 0$ & 219 & $0 \cdot 16$ \\
\hline
\end{tabular}

* Body weight was not reported, and is assumed to be $500 \mathrm{~kg}$ in the calculation.

$\uparrow$ Recalculated assuming digestible organic matter intake $=0 \cdot 90$ DDMI.

\$ Recalculated assuming endogenous contribution to be $0.385 \mathrm{mmol}$ purine derivatives $/ \mathrm{kg} \mathrm{W}^{0 \cdot 75}$ per $\mathrm{d}$.

values obtained from Bos taurus cattle (18.5 mmol PD/ $\mathrm{kg}$ DOMI reported by Giesecke $e t$ al. (1993), and $18.4 \mathrm{mmol}$ PD/kg DOMI by Daniels, 1993) assuming that the same digestibility of microbial purines in the small intestines applies to both species of animals. Although the use of different diets in the different experiments contributes to part of the difference in the rate of PD excretion per unit digestible feed intake, the difference noted here is threefold and cannot be fully accounted for by the dietary differences. The results of this work are in agreement with those of Vercoe (1976) and Liang et al. (1993) in that allantoin excretion per unit feed intake in buffaloes was lower than in cattle. Table 3 summarizes the results reported in the literature on the response of allantoin excretion to the level of digestible DM intake (PD excretion is not tabulated since only allantoin was measured in some of the experiments). It can be seen clearly that allantoin excretion rate was $14.24 \mathrm{mmol} / \mathrm{kg} \mathrm{DDMI}$ for cattle (Bos taurus and Bos indicus) and was consistently higher than that seen in buffaloes $(4-8 \mathrm{mmol} / \mathrm{kg}$ DDMI).

\section{Xanthine oxidase activities in buffaloes, cattle and sheep}

This work clearly demonstrates that buffaloes have higher $\mathrm{XO}$ activities in the tissues examined (plasma, liver and intestine) than sheep and cattle. It is the first time that measurements of XO activity in the buffalo have been reported. The patterns of tissue distribution of XO activities in cattle and sheep (Expt 3 ) were in agreement with the results of Al-Khalidi \& Chaglassian (1965) and of Chen et al. $(1990 \mathrm{c})$. The plasma XO in cattle measured in the present study $(1.4$ unit/1) was close to the 1.13 unit/1 reported by Chen et al. $(1990 \mathrm{c})$. All values for XO activities obtained in the present study for sheep and cattle were, however, higher than those reported by Al-Khalidi \& Chaglassian (1965), probably because in the assay procedure used in the present study L-histidine was included to prevent a possible inhibition of $\mathrm{XO}$ activity by excess substrate. It should be noted that since the 
samples used for measurement of $\mathrm{XO}$ activity in the present study were taken randomly with regard to age, breed, sex and previous nutritional status of the animals, our results do not provide any indication of the effects of these factors on XO activity.

In buffaloes the remarkably high XO activities in the intestinal mucosa and the liver would also suggest that extensive conversion of exogenous purines into uric acid takes place in the course of absorption, thus making absorbed exogenous purines unavailable for direct incorporation into tissue nucleotides. Cattle also have a high activity of XO in the intestinal mucosa and an extensive conversion of absorbed purines into uric acid in the intestinal mucosa has been demonstrated in cattle (Balcells et al. 1992). As a result, urinary PD excretion would be expected to be a linear function of the exogenous purine uptake. Such a relationship has been observed in cattle (Verbic et al. 1990). The apparently linear relationship between PD excretion and feed intake noted in Expt 2 indicates that a linear relationship between $\mathrm{PD}$ excretion and exogenous purine absorption is probably also to be found in buffaloes.

\section{Difference between cattle and buffaloes}

From the observations made in the present study and in the literature, it seems that PD excretion in buffaloes is lower than in cattle. Large differences in endogenous PD excretion between sheep $\left(0 \cdot 168 \mathrm{mmol} / \mathrm{kg} \mathrm{W}^{0.75}\right.$ per $\left.\mathrm{d}\right)$ and cattle $\left(0.530 \mathrm{mmol} / \mathrm{kg} \mathrm{W}^{0.75} \mathrm{per} \mathrm{d}\right)$ may be partly attributed to the differences in their tissue XO activities (Chen et al. 1990 c). A higher $\mathrm{XO}$ activity results in a greater amount of purines being converted to $\mathrm{PD}$. In view of the $\mathrm{XO}$ activity in buffaloes and similarity between buffaloes and cattle in the pattern of PD excretion, it is surprising to note that both the estimated endogenous PD excretion and the excretion per $\mathrm{kg}$ feed digested in buffaloes was lower than in cattle. The latter could be partly due to a difference in the efficiency of microbial protein supply (i.e. amount of microbial biomass flowing to the small intestine per unit feed fermented) or a difference in the digestibility of microbial purines. However, feed-related factors would not explain the lower fasting excretion. It is also interesting to note that similar differences were present with other urinary metabolites: (1) creatinine excretion of buffaloes $(0 \cdot 33-0.44 \mathrm{mmol} / \mathrm{kg}$ $\mathrm{W}^{0.75}$ per d) was also lower than that in cattle $\left(0.90-1.00 \mathrm{mmol} / \mathrm{kg} \mathrm{W}^{0 \cdot 75}\right.$ per $\mathrm{d}$; Chen et al. 1992; Daniels, 1993); (2) the fasting $\mathrm{N}$ excretion measured in the present study was $257 \mathrm{mg} / \mathrm{kg} \mathrm{W}^{0.75}$ per $\mathrm{d}$, and the endogenous excretion would be lower since fasting generally leads to an elevated $\mathrm{N}$ excretion. Even if the value is taken as the endogenous excretion, the latter is still lower than the endogenous excretion for cattle of approximately $350 \mathrm{mg} / \mathrm{kg} \mathrm{W}^{0.75}$ per d (summarized by the Agricultural Research Council, 1984). Gupta et al. (1966) and Moran (1983) reported even lower fasting $\mathbf{N}$ excretion values (92-96 $\mathrm{mg} \mathrm{N} / \mathrm{kg} \mathrm{W}^{0.75}$ ) for buffaloes than that in the present study. Considering all three aspects, it appears to us that a common factor causing the observed differences between cattle and buffaloes may have been the proportion of plasma metabolites that was cleared by the kidney. In line with this argument is the observation by Norton et al. (1979) that buffaloes had a lower glomerular filtration rate than cattle at the same feed intake and body weight. Buffaloes could have evolved a mechanism to recycle more $\mathrm{N}$ to the rumen via saliva than cattle. PD can also be recycled into the rumen in this way and such recycled PD cannot be recovered in the urine (Chen et al. 1990a). Our argument effectively implies that the amount of PD of endogenous origin, and the amount of PD per unit intake of exogenous purines released into the circulation in buffaloes could be comparable with or even higher than those in cattle, but that a lower proportion of the plasma PD is cleared by renal excretion. This argument needs to be supported by direct measurement of this proportion. In sheep and cattle the proportion of plasma PD cleared by renal excretion is about $85 \%$ (Chen et al. 1991). 
In summary, the present study indicates that buffaloes are similar to cattle in the profile of PD excreted in urine, and have a similar pattern of tissue distribution of XO but at higher activities than in cattle. However, in buffaloes the fasting PD excretion and the PD excretion per unit digestible feed intake are lower than in cattle. Fasting $\mathbf{N}$ excretion and creatinine excretion are also lower than in cattle. The reason for these differences is not clear. It is possible that in buffaloes a greater proportion of purine metabolites in plasma are disposed of via a non-renal route. The nutritional implication of these differences has yet to be explored. To establish a method for estimating intestinal microbial protein flow based on PD excretion in buffaloes, future work will need to focus on defining the partitioning factor between renal and non-renal routes for disposal of plasma PD.

This work was supported by a grant from the Natural Resources, Energy and Science Authority for Sri Lanka (NARESA) and Swedish Agency for Research Cooperation with Developing Countries (SAREC). The authors thank Dr N. Perera for his support in the experimental work, and Drs D. Scott and R. N. B. Kay for their criticism of the manuscript.

\section{REFERENCES}

Agricultural Research Council (1984). The Nutrient Requirements of Ruminant Livestock, Supplement no. 1 Slough: Commonwealth Agricultural Bureaux.

Al-Khalidi, U. A. S. \& Chaglassian, T. H. (1965). The species distribution of xanthine oxidase. Biochemical Journal 97, 318-320.

Association of Official Analytical Chemists (1965). Official Methods of Analysis of the Association of Official Analytical Chemists, 10th ed., pp. 327-328. Washington, DC: AOAC.

Balcells, J., Guada, J. A., Castrillo, C. \& Gasa, J. (1991). Urinary excretion of allantoin and allantoin precursors by sheep after different rates of purine infusion into the duodenum. Journal of Agricultural Science, Cambridge 116, 309-317.

Balcells, J., Parker, D. S. \& Seal, C. J. (1992). Purine metabolite concentrations in portal and peripheral blood of steers, sheep and rats. Comparative Biochemistry and Physiology 101B, 633-636.

Chen, X. B., Grubic, G., Ørskov, E. R. \& Osuji, P. (1992). Effect of feeding frequency on diurnal variation in plasma and urinary purine derivatives in steers. Animal Production 55, 185-191.

Chen, X. B., Hovell, F. D. DeB. \& Ørskov, E. R. (1990a). Excretion of purine derivatives by ruminants: recycling of allantoin into the rumen via saliva and its fate in the gut. British Journal of Nutrition 63, 197-205.

Chen, X. B., Kyle, D. \& Ørskov, E. R. (1993). Measurement of allantoin in urine and plasma by high-performance liquid chromatography with pre-column derivatization. Journal of Chromatography 617, 241-247.

Chen, X. B., Mathieson, J., Hovell, F. D. DeB. \& Reeds, P. J. (1990 b). Measurement of purine derivatives in urine of ruminants using automated methods. Journal of the Science of Food and Agriculture 53, 23-33.

Chen, X. B., Ørskov, E. R. \& Hovell, F. D. DeB. $(1990 \mathrm{c})$. Excretion of purine derivatives by ruminants: endogenous excretion, differences between cattle and sheep. British Journal of Nutrition 63, 121-129.

Chen, X. B., Ørskov, E. R. \& Hovell, F. D. DeB. (1991). The use of intragastric infusion in studies on excretion of purine derivatives as a measure of microbial protein supply in ruminants. In Protein Metabolism and Nutrition. Proceedings of the 6th International Symposium on Protein Metabolism and Nutrition, vol. 2, pp. 67-70 [B. O. Eggum, S. Boisen, C. Børsting, A. Danfær and T. Hvelplund, editors]. Foulum, Denmark: National Institute of Animal Science.

Daniels, Z. M. (1993). Purine derivatives in urine and plasma of lactating cows given different levels of feed intake. MSc Thesis, Aberdeen University.

Dewhurst, R. J. \& Webster, A. J. F. (1992). Effects of diet, level of intake, sodium bicarbonate and monensin on urinary allantoin excretion in sheep. British Journal of Nutrition 67, 345-353.

Furth-Walker, D. \& Amy, N. K. (1987). Regulation of xanthine oxidase activity and immunologically detectable protein in rats in response to dietary protein and iron. Journal of Nutrition 117, 1697-1703.

Giesecke, D., Balsliemke, J., Suderum, K.-H. \& Stangassinger, M. (1993). Plasma level, clearance and renal excretion of endogenous and ruminal purines in the bovine. Journal of Animal Physiology and Animal Nutrition 70, $180-189$.

Gupta, B. S., Bhargwa, V. N., Raina, N. N. \& Singh, S. N. (1966). Studies on endogenous and metabolic faecal nitrogen in buffaloes. Indian Journal of Veterinary Science 36, 90-95.

Hashimoto, S. (1974). A new spectrophotometric assay method of xanthine oxidase in crude tissue homogenate. Analytical Biochemistry 62, $426-435$.

Larsen, K. (1972). Creatinine assay by reaction-kinetic principle. Clinica Chimica Acta 41, 209-217.

Lawes Agricultural Trust (1983). Genstat 4 User Manual. Harpenden: Rothamsted Experimental Station. 
Liang, J. B., Matsumoto, M., Ishida, M. \& Young, B. A. (1993). Urinary allantoin excretion in Malaysian cattle and buffaloes. In Proceedings of 7th World Conference on Animal Production, pp. 58-59. Alberta, Canada: University of Alberta.

Lindberg, J. E. (1989). Nitrogen metabolism and urinary excretion of purines in goat kids. British Journal of Nutrition 61, 309-321.

Lindberg, J. E. \& Murphy, M. (1991). Rumen metabolism, excretion of purine derivatives and milk composition in dairy cows fed rations with negative and positive protein balance values in the rumen. In Protein Metabolism and Nutrition. Proceedings of the 6th International Symposium on Protein Metabolism and Nutrition, vol. 2, pp. 336-337 [B. O. Eggum, S. Boisen, C. Børsting, A. Danfær and T. Hvelplund, editors]. Foulum, Denmark: National Institute of Animal Science.

Maloiy, G. M. O., Kay, R. N. B., Goodall, E. D. \& Topps, J. H. (1970). Digestion and nitrogen metabolism in sheep and red deer given large or small quantities of water and protein. British Journal of Nutrition 24, 843-855.

Moran, J. B. (1983). Aspects of nitrogen utilization in Asiatic water buffalo and Zebu cattle. Journal of Agricultural Science, Cambridge 100, 13-23.

Mura, U., Osman, A. M., Mohamed, A. S. \& Ipata, P. L. (1986). Studies on purine turnover in the camel (Camelus dromedarius) and Zebu (Bos indicus). Comparative Biochemistry and Physiology 84B, 589-593.

Muraoka, S. (1963). Studies on xanthine oxidase. 2. Biochimica et Biophysica Acta 73, 27-38

Norton, B. W., Moran, J. B. \& Nolan, J. V. (1979). Nitrogen metabolism in Brahman cross, buffalo, Banteng and Shorthorn steers fed on low-quality roughage. Australian Journal of Agricultural Research 30, 341-351.

Ross, G. J. S. (1987). MLP User Manual. Rothamsted: Rothamsted Experimental Station.

Verbic, J., Chen, X. B., MacLeod, N. A. \& Ørskov, E. R. (1990). Excretion of purine derivatives by ruminants: effect of microbial nucleic acid infusion on purine derivative excretion by steers. Journal of Agricultural Science, Cambridge 114, 243-248.

Vercoe, J. E. (1976). Urinary allantoin excretion and digestible dry matter intake in cattle and buffalo. Journal of Agricultural Science, Cambridge 86, 613-615. 